HALinA RATYŃSKA ${ }^{1}$, MARIAN GRODZKI ${ }^{2}$, BARbARA WALDON ${ }^{1} \&$ EWA WACHOWIAK $^{1}$

${ }^{1}$ Kazimierz Wielki University, Institute of Environmental Biology, Department of Botany, Ossolińskich 12, 85-093 Bydgoszcz

${ }^{2}$ Poznań University of Life Sciences, Experimental-Educational Unit of Forest Arboretum in Zielonka, Zielonka 6, 62-095 Murowana Goślina

\title{
INTRODUCTION OF ALIEN TREE SPECIES AND ITS INFLUENCE ON FLORISTICAL COMPOSITION AND VEGETATION STRUCTURE OF ACIDOPHILOUS OAK FORESTS: THE EXPERIMENTAL PLOTS IN THE ZIELONKA FOREST
}

\begin{abstract}
In 1879 Schwappach first established 54 experimental forest plots on habitat of acidophilous oak forest Calamagrostio-Quercetum in the Zielonka Forest near Poznań, on which 20 exotic tree species were cultivated. Until this day 32 of the mentioned forest sites have been preserved and today only 9 species are present there. The aim of the study was to determine actual condition of the experimental plots, a description of their flora and vegetation, as well as a comparison with other test plots situated in the direct neighbourhood. Basing on 63 phytosociological relevés, an influence of exotic species plantings on the structure of vegetation and local biodiversity was assessed. Floristic richness of both experimental plots (88 species), as well as their direct neighbourhood (68) was recognised, along with the geographical-historical groups spectrum and species affiliation to phytosociological classes.
\end{abstract}

Key words: experimental plots, alien tree species, flora, the Zielonka Forest 


\section{INTRODUCTION}

Since the end of the $19^{\text {th }}$ century numerous exotic tree species, mainly coming from North America, have been cultivated in forests in various regions of Europe. In Poland, in areas formerly annexed by German Prussia, such experimental plantings were established by Schwappach and by his successor Wiedemann (BELlON et al. 1977). They wanted to obtain new species for cultivation, characterised by increased productivity comparing with those of native taxa.

Indeed, effects of an introduction of alien tree species may be assessed only after a relatively long time, but just in a dozen or so years since establishment of the experiment it turned out that many species and varieties were useless for forestry or they became exinct (e.g. ReICHENAU 1911; HeRMANN 1911). Moreover, not all experimental plots have survived until present times (BIAŁOBOK, CHYLARECKI 1965). Thus, the preserved forest stands dominated by anthropophytes seem to be even more precious for research and practical purposes. In many publications (e.g. BELLON et al. 1977) such features as: development, productivity, susceptibility to infections or potential adaptation to our climate, were analysed in relation to exotic tree species. The presented paper, focusing on phytocoenological analysis, differs from this trend and in this way it fills the gap in our knowledge about the influence of introduced alien tree species on local phytocoenoses.

In 1879, in the Zielonka Forest near Poznan, Schwappach established his first experimental plots within a homogeneous habitat of the acidophilous oak forest. In these sites 20 alien tree species have been cultivated. The state of preservation of these sites after ca. half a century since their establishment, was described by MiKLASZEWSKI (1928). A comparison of data obtained more than 100 years ago with results of other investigations carried out in the 1950s (KOSTURKIEWICZ, MEIXNER 1956) and our contemporary research enable us to make an assessment of changes which took place in forest communities as a result of alien species introduction, as well as to reveal that most of tree species originating from different climatic zones failed in cultivation.

The main aims of the study comprised: an assessment of a state of preservation of experimental plots in comparison with data collected in 1954 
(KosturkiewiCZ, MeIXNER 1956), a description of flora and vegetation of the experimental and test plots, and on this basis - a determination of an effect of exotic species plantings on the vegetation structure and on the local biodiversity of experimental plots.

\section{GENERAL DESCRIPTION OF THE INVESTIGATED AREA}

According to the physical-geographical division of Poland (KONDRACKI 1998) the investigated area is situated in the Macro-region of the Wielkopolskie Lakeland (315) and comprises a part of the Gnieźnieńskie Lakeland Meso-region (315.54). The absolute altitude fluctuates between 107 and $121 \mathrm{~m}$ a.s.l. The matrix of soils was shaped by the last glaciation, during the so-called Frankfurt and the Vistulian period. They are classified as podsolic soils, poorly or moderately developed of slightly clayish sands, with ca. pH 6 in the humus layer. The groundwater level lays below 2 $m$ under the soil surface (KOSTURKIEWICZ, MEIXNER 1956).

As far as the climate is concerned, according to WoŚ (1996), it is the MiddleWielkopolska Region (XV) characterised by moderate features related to neighbouring regions: a low precipitation, late ground frosts observed sporadically even in May and early frosts appearing sometimes in the third decade of September. According to data obtained from a meteorological station in the Zielonka Arboretum, the mean annual temperature is $8.1^{\circ} \mathrm{C}$, the mean temperature of January is $-2.2^{\circ} \mathrm{C}$, in July $+18.1^{\circ} \mathrm{C}$, the many years' minimum is $-32.4^{\circ} \mathrm{C}$, whereas the longterm maximum is $+35.0^{\circ} \mathrm{C}$. The mean annual precipitation is ca. $540 \mathrm{~mm}$.

The experimental plots with alien species are situated in the Zielonka Experimental Forestry District belonging to the Poznań University of Life Sciences. They are located in a large forest complex, in the section No. 121a, and their total area is 27.93 ha. The potential natural vegetation is classified as representing the acidophilous oak forest Calamagrostio arundinaceae-Quercetum. Both compared test plots, as well as surrounding forest stands are quite well developed and preserved patches of the mentioned acidophilous oak forests.

In the classification of forest habitats it is the fresh mixed broadleaved forest (LMśw) with various-age stands of: Scots pine Pinus sylvestris - ca. 95 yrs old, oak 
Quercus robur - $110 \mathrm{yrs}$ old, and as an example of exotic species, the coast Douglas-fir Pseudotsuga manziesii reaching an age of up to 140 years. The mean diameter at breast height in case of Scots pines is $31 \mathrm{~cm}$, while the tree's mean height is $26 \mathrm{~m}$, whereas these measure for oaks are respectively: $36 \mathrm{~cm}$ d.b.h. and 27 m. Sanitation cuttings have often been made in forest plantations, whereas tending interventions had never been done, which have resulted in a relatively high density of the tree layer.

\section{MATERIAL AND METHODS}

We used data taken from a publication by KostUrKIEWICZ and MEIXNER (1956) and the results of our own field investigations carried out in the vegetation season of 2008. Own observations show that only 32 of 54 plots established over 100 years ago have been preserved until now, including just 22 sites with closed tree stand. Initially there were 20 cultivated species but only 9 of them have survived (Table 1).

Table 1. A list of cultivated species and the number of occupied plots.

\begin{tabular}{lcc}
\hline \multicolumn{1}{c}{ Species } & $\begin{array}{c}\text { Number of plots } \\
\text { in 1956 }\end{array}$ & $\begin{array}{c}\text { Number of plots } \\
\text { in 2008 }\end{array}$ \\
\hline Abies nordmanniana & 5 & 5 \\
Betula lenta & 1 & 1 \\
Carya cordiformis & 3 & 3 \\
Carya ovata & 5 & 4 \\
Chamaecyparis lawsoniana & 2 & 2 \\
Fraxinus Americana & 11 & 3 \\
Pinus strobus & 2 & 1 \\
Pseudotsuga menziesii & 6 & 2 \\
Thuja plicata & 14 & 11 \\
\hline
\end{tabular}

As far as the health condition of trees is considered, the only species with a good vitality were: Pseudotsuga menziesii, Carya cordiformis and C. ovata. It should be mentioned that old individuals of the two last species were cut off during 
the Second World War, so there was a next generation of shagbark hickory growing in the plots. Chamaecyparis lawsoniana and Thuja plicata were infected by brown root fungus Fomes annosus, which was reported even by KOSTURKIEWICZ and MEIXNER in 1956. Pinus strobus was infected by rust Cronartium ribicola. Individuals of Fraxinus americana and Betula lenta were characterised by a diminished vitality, which may be attributed to their age.

Species which have not survived (i.e. destroyed plots) comprise: Abies alba, A. concolor, Acer negundo, Catalpa speciosa, Juniperus virginiana, Larix kaempferi, Picea engelmanni, P. pungens, P. sitchensis, Quercus rubra and Zelkova errata.

The material comprises altogether 63 phytosociological relevés made (200 $\mathrm{m}^{2}$, according to the well-known Braun-Blanquet's method) in the preserved experimental plots ( 32 of relevés) $(0.05-0.42$ ha) and in their direct vicinity (31 of relevés). On this basis we assessed an effect of exotic species plantings on the vegetation structure and biodiversity. Local floristic richness (vascular plant species and mosses) of experimental plots and their neighbourhood was determined. We also analysed a spectrum of geographical-historical groups and life forms of plants in both cases using a classification of species according to JACKOWIAK (1990), and affiliation of taxa to phytosociological classes - according to BRZEG and WOJTERSKA (2001). Names of vascular plant species were used after RUTKOWSKI (2007).

The phytosociological relevés of gradient were analysed using the program MVSP (KovACH 2002). The Braun-Blanquet scale was transformed to van der Mareel 9-degree scale (VAN DER MAREEL 1979). We used quantitative and qualitative data to compatibility analysis (DCA). 


\section{RESULTS}

The monolayer or two-layer forest structure of experimental plots consist mainly with Quercus petraea with an admixture of Pinus sylvestris. A density of trees is fairly even and varies from 40 to $80 \%$ in the layer a1 and up to $70 \%$ in a2. The forest stand of alien trees species is most commonly monolayer. A density of trees is very different: from very high $(85 \%)$ to gaps completely devoid of trees. A high density of trees is characteristic of stand with Carya cordiformis, C. ovata, Chamaecyparis lawsoniana and Thuja plicata. The lower tree layer, which consists mainly of species of the genus Carya and Fraxinus pensilvanica reaches 50\%.

A brushwood is comparable and not very high (up to 20\%), both in control and experimental plots. A distinct difference in the coverage of ground cover is emphasised: in the experimental plots, dominated by coniferous trees growing in a large density it is very minor, but increases, up to $80 \%$, under the tree cover of deciduous trees. In the control plots the coverage of herb layer is more aligned, it hesitates from minimal to $75 \%$, on average approximately $40 \%$.

The moss layer in the control plots is less developed, occasionally reaches $25 \%$. Whereas in the experimental plots, especially under the tree cover of Abies normandiana, Pinus strobus and Pseudotsuga menziesii the coverage reaches up to $80 \%$.

A tendency to natural seedling and regeneration, that is also a potential expansion was shown mainly by Carya cordiformis and Carya ovata, also to a lower extent by Pseudotsuga menziesii. In case of Abies nordmanniana, Chamaecyparis lawsoniana and Thuja plicata, which germinated rather abundantly, the dying out of 3-4 years old seedlings was observed.

Total flora of the experimental plots and in the directly neighbouring with them control plots was composed of 98 species, 21 of which were mosses. Flora of the experimental plots (88 taxa, including 21 mosses) was richer than in their neighbourhood (only 68 species, including 8 mosses). More abundant in species, and at the same time more heterogeneous were the stands with coniferous plantings (70 species). In stands with loose tree layer we recorded 55 species, whereas in the plots with dense coniferous plantings - 51 taxa. In the sites with deciduous trees 63 
species were observed. There were 44 common taxa (45\%) which were present both in the experimental plots and their vicinity.

Eigenvalues of axis diagram obtained by indirect analysis (DCA) indicate that the gradient represented by the first axis differentiates significantly the occurrence of species and explains $6.5 \%$ of the variability of vegetation, and the other axis $-5.5 \%$. Consulting diagram allowed to distinguish four groups of phytosociological relevés (indicated by ellipses in Fig. 1):

A - Records made on experimental plots with species of the genus Carya in the highest layers of the forest stands, the most different from the control plots;

B - Records made on experimental plots with Betula lenta and Fraxinus americana, which mostly relate to the control plots;

$\mathrm{C}$ - Records made on experimental plots with coniferous plantings; Records with the smallest density of trees and concurrently with larger coverage in ground cover and mosses are closer to the control plots. (e.g. records 14a-24a);

D - Records in the control plots, which are devoid of alien planting, creates the most homogenous group (Fig. 1).

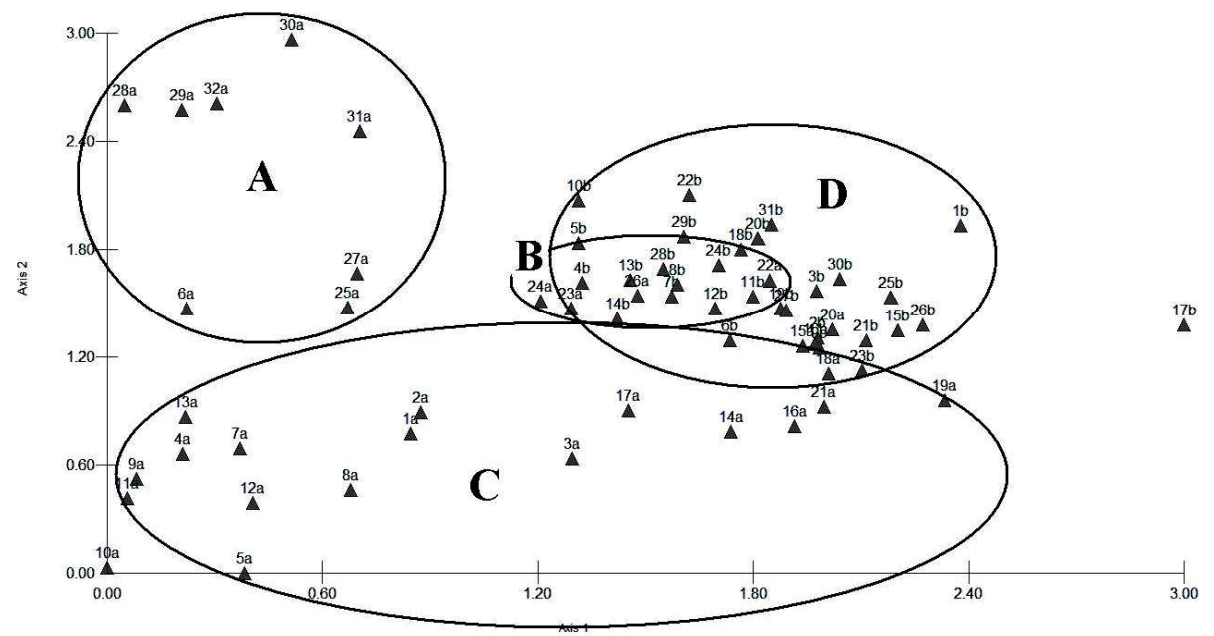

Fig. 1. Results of the indirect analysis DCA (MVSP) of records made in the experimental plots (a) and in the direct vicinity (b). A - patches with Carya cordiformis and C. ovata, B - patches with Betula lenta and Fraxinus americana, C - patches with coniferous plantings, D - control plots. 
In all investigated plots native species were dominating, particularly the nonsynanthropic spontaneophytes (Fig. 2). Alien taxa were slightly more represented in the experimental plots. Among the life form spectrum the most frequent were hemicryptophytes which were more numerous in the experimental plots (Fig. 3). The presence of phanerophytes was considerably high (21 species). Significantly numerous herbaceous chamaephytes were recorded in the experimental plots which may be explained by a relatively high share of mosses. In the experimental plots, particularly in those dominated by broadleaved tree stands, more species with short life cycles (therophytes) were noticed.

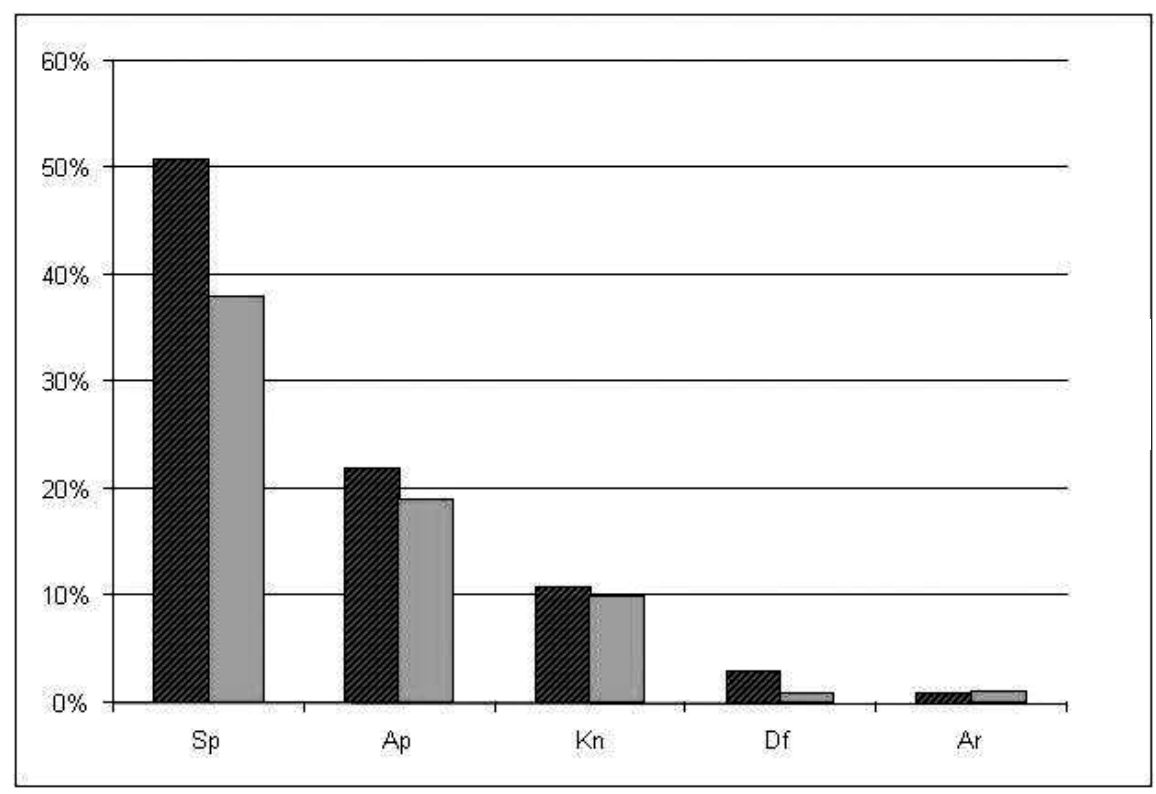

Fig. 2. Number of species representing historical-geographical groups in the flora of the experimental plots and in directly neighbouring. Sp - spontaneophytes, Ap - apophytes, Ar - archeophytes, Kn - kenophytes, Df - diaphytes, experimental plots (black bars), neighbouring control plots (grey bars).

Floristical composition of the investigated communities was dominated by acidophilous species representative of the Quercetea robori-petraeae and the Vaccinio-Piceetea classes (the most numerous in experimental plots, particularly in those with coniferous tree plantings). Some plants of relatively higher trophic 
requirements were also present, i.e. species diagnostic of the classes: QuercoFagetea (which were slightly less frequent in the experimental plots with coniferous tree stands) and Artemisietea (Fig. 4). Taxa regarded as characteristic of other

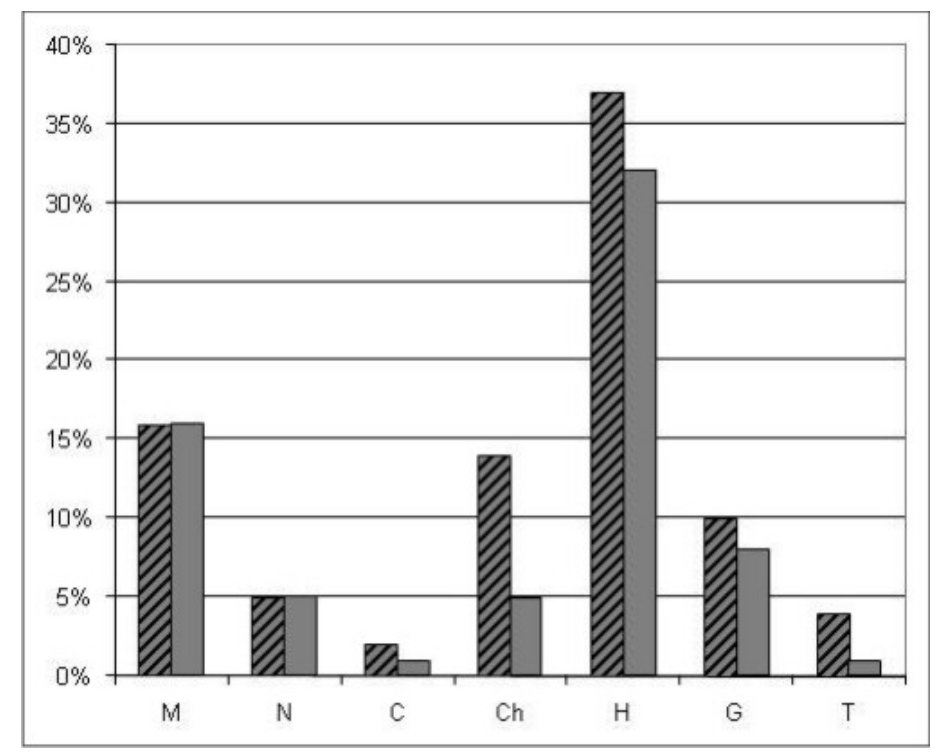

Fig. 3. Percentage of vascular plant life forms in the flora of the experimental and control plots in the Zielonka Forest. M - megaphanerophytes, $\mathrm{N}$ - nanophanerophytes, Ch - lignify chamaephytes, C - chamaephytes, G - geophytes, H - hemicryptophytes, Hy - hydrophytes, T - terophytes, experimental plots (dashed bars), control plots (grey bars).

classes appeared only exceptionally. It was noticeable that particularly in experimental plots, the number of companion taxa was significantly higher.

\section{DISCUSSION}

To this day ca. 59\% of the former experimental plots have survived, many tree stands of which are in their terminal stages, whereas only $40 \%$ have more or less close stands. In the investigated area there are still the largest in Poland tree stands of Thuja plicata (BELLON et al. 1977).

A relatively poor habitat, with upper soil level in some places additionally acidified in consequence of an introduction of coniferous trees, is the main reason 
why the investigated plant communities are not rich in species. The relatively higher floristical richness of the experimental plots resulted not only from the presence of the introduced tree species, but may also be attributed to a spontaneous encroachment of other plants into stands with lower tree density and the herb layer in some places disturbed by wild boars, which is more often observed within experimental plots. More rich, and at the same time more heterogeneous as far as the floristical composition is considered, were the stands with coniferous plantings. On the other hand, patches with a high density of the tree layer, and consequently a poor sun exposure of the forest floor, were floristically the poorest ones (i.e. only 50 species). The number of common taxa for both the experimental plots and their vicinity was 44 (i.e. $45 \%$ ), which may indicate a high heterogeneity of analysed sites, particularly the experimental plots. This is confirmed by the results of statistical analysis (Fig. 1), which indicate a relatively high homogeneity of the neighbourhood (patches of acidophilous oak forest - D) and high heterogeneity of the experimental area - A-C. The consulting diagram shows that the most important determinants of phytosociological relevés are species composition of planting and density of tree layers having an impact on the formation of the lower layers of phytocoenoses. An important factor can be also a change of the properties of the substrate, e.g. due to decomposition leaf processes of alien species. In patches with mature specimens Carya reported an increase in the proportion of species from richer habitats from Artemisietea class compared with the control areas.

A small contribution of anthropophytes in all investigated stands resulted from the situation of the plots within a large forest complex which caused a limited inflow of alien species diaspores, excepting the introduced trees.

In the biological spectrum, similarly as it was calculated for the whole Poland (cf. Kornaś, MedweCKA-KornaŚ 1986; MATUSZKIEwICZ 1990), the dominant life form were hemicryptophytes. A relatively high number of phanerophytes was a consequence of an introduction of alien trees and their self sowing not only within but also in the neighbourhood of the plots. A percentage share of trees would significantly diversify the experimental plots and their vicinity if their presence is analysed in particular vegetation layers. A higher presence of therophytes in the 
experimental plots, and particularly in those sites with broadleaved tree stands, may be attributed to available ecological niches provided by digging boars and also as a result of loosen tree stands.

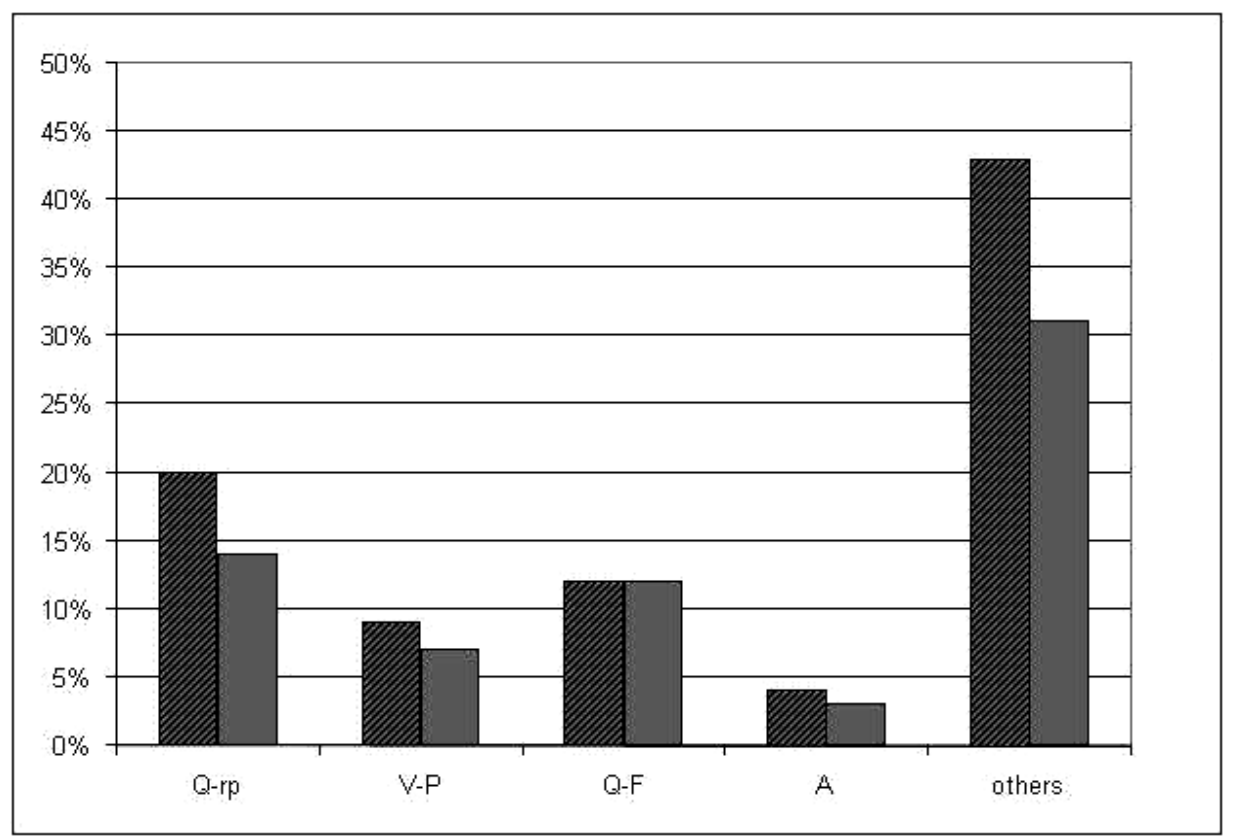

Fig. 4. Percentage of the phytosociological groups of the experimental and control plots in the Zielonka Forest. Q-rp - Quercetea robori-petreae, V-P - VaccinioPiceetea, Q-F - Querco-Fagetea, A - Artemisietea, experimental plots (black bars), neighbouring control plots (grey bars).

Analysis of the presence of diagnostic species of various phytosociological classes indicated that acidophilous taxa were dominant and particularly numerous in the experimental plots, mainly in those with conifer stands, the litter of which additionally acidified the soil, thus contributing to its degeneration. KUCABA (1980) demonstrated that western redcedar acidifies soils to a smaller extent than spruce, and that the litter of the former species decomposes faster, but at the same time the stands with Thuja plicata and Chamaecyperis lavsoniana are the most dense, and as such they have the most shaded and the poorest-in-species forest floor. The presence of the representatives of Artemisietea, although not high, is also an indicator of 
disturbances in forest vegetation. They were the most numerous in broadleaved tree stands which indicates the lowest acidity of their top soil levels.

In comparative test sites, situated in a direct vicinity of the experimental plots, the dominant vegetation type was the acidophilous oak forest. Some phytocoenoses demonstrated signs of degeneration processes, i.e. of the so-called 'pinetisation' (OLACZEK 1972, 1974). In such patches the seedlings of introduced trees were found. Vegetation of the experimental plots, with old tree stands composed of introduced species, should be treated as the so-called 'substitute forest communities'. Apart from significant floristical differences in relation to the control plots, the vertical structure of such phytocoenoses was strongly modified: from highly dense stands, without underwood and shrubs and with a very poor forest floor, up to irregularly stocked open stands with scattered trees and a luxuriant herb layer.

Among patches with Carya ovata and in their vicinity we even observed an invasion of shagbark hickory. CHYLARECKI (1963) and BELLON et al. (1977) reported that in Poland and particularly in Silesia this species passes the complete life cycle and it regenerates through self sowing.

It is interesting that both KosturKIEWICZ and MEIXNER (1956), as well as authors of the presented article have never found brown root in the neighbouring pine stands. Introduced taxa were probably the only species infected by any fungus diseases.

\section{CONCLUSIONS}

- Only few species of the introduced alien trees were able to overcome the environmental resistance and to survive in the same places for over 100 years. Merely four of them formed close stands and three remained in a good health.

- Differences in the vegetation structure of the experimental plots manifested in: a degree of survival of the tree layer (from insignificantly present to very dense stands), the diversified coverage of the herb layer (i.e. insignificant under a canopy of dense tree stands and luxuriantly developed in patches with wellspaced stands). 
- Flora of the experimental plots and their direct vicinity, due to the habitat potential, was not particularly rich-in-species. More taxa (by ca. 24\%) were recorded in the experimental plots.

- The introduction of alien trees into a compact forest area has caused changes in floristical composition not only within the experimental plots, but also in their vicinity (self sowing of some species). More anthropophytes were found in the experimental plots than in the control plots.

- Higher changes in the floristical composition and structure of phytocoenoses were noticeable in coniferous stands, particularly in those with a high canopy density. The decisive factor for floristic richness in patches was rather an access to sunlight (the shade in the herb layer) than the appearance of cultivated tree species. Changes of the properties of the soil caused by planting alien taxa may also be significant. A continuous local extinction of alien species should be predicted, mainly in consequence of a natural ageing process. The only species showing a high dynamics of natural regeneration is Carya ovata, which becomes a permanent component of the flora of the Zielonka Forest.

\section{REFERENCES}

BELlon, S., TuMiŁOWICZ, J., KRóL, S. 1977. Obce gatunki drzew w gospodarstwie leśnym. PWRiL, Warszawa.

BiaŁoboK, S., Chylarecki, H. 1965. Badania nad uprawą drzew obcego pochodzenia w Polsce w warunkach środowiska leśnego. Arboretum Kórnickie r. 10.

Brzeg, A., WoJTERsKa, M. 2001. Zespoły roślinne Wielkopolski, ich stan poznania i zagrożenie. In: M. WoJTERsKA (ed.), Szata roślinna Wielkopolski i Pojezierza Południowopomorskiego. Przewodnik sesji terenowych 52. Zjazdu PTB, 24-28 września 2001, Bogucki Wydawnictwo Naukowe, Poznań, pp. 39-110.

ChYlarecki, H. 1963. Badania nad przeorzechami (Carya Nutt.) uprawianymi w Polsce w warunkach środowiska leśnego. Arboretum Kórnickie r. 8. 
HermanN, 1911. Verhalten und Gedeichen der ausländischen Holzgewächse in Westpreussen mit spezieller Berücksichtigung der Versuchsflächen in der Oberförsterei Wirthy. Mitt. dDDG.

JACKOWIAK, B. 1990. Antropogeniczne przemiany flory roślin naczyniowych Poznania. Wydawnictwo UAM, s. B. 42, Poznań, pp. 1-234.

KondRACKI, J. 1998. Geografia fizyczna Polski. Wydawnictwo Naukowe PWN, Warszawa.

KoRnAŚ, J., MEDWECKA-KoRnAŚ, A. 1986. Geografia roślin. PWN, Warszawa.

Kosturkiewicz, A., MeIXner, J. 1956. Chamaecyparis Lawsoniana Parl. i Thuja plicata Lamb. na terenie Nadleśnictwa Państwowego Łopuchówko. Roczn. Dendr. 11: 195-224.

Kovach, W.L. 2002. Multivariate Statictical Package. Version 3.1. Pentraeth. Wales. U. K.

KuCABA, S. 1980. Wpływ niektórych drzewostanów na właściwości poziomu akumulacji biologicznej. Fol. For. Pol. ser. A, 24: 43-63.

MatusZKiewicz, W. 1990. Regionalizacja geobotaniczna. In: T. TRAmPLER, A. KLICZKowsKa, E. DMYTERKo, A. SierpińskA (eds), Regionalizacja przyrodniczo-leśna na podstawach ekologiczno-fizjograficznych. PWRiL, Warszawa, pp. 134-157.

MiKLASZEWSKI, J. 1928. Lasy i leśnictwo w Polsce. T. 1. Warszawa.

OLACZEK, R. 1972. Formy antropogenicznej degenacji leśnych zbiorowisk roślinnych w krajobrazie rolniczym Polski Niżowej. Wydawnictwo UŁ, pp.1120.

OlACZEK, R. 1974. Etapy pinetyzacji grądu. Phytocoenosis 3(3/4): 201-214.

REICHENAU, 1911. Ausländische Holzarten in den Forsten des Regierungsbezirks Danzig. Mitt. dDDG.

RUTKOWSKI, L. 2007. Klucz do oznaczania roślin naczyniowych Polski niżowej. Wydawnictwo Naukowe PWN, Warszawa.

WoŚ, J. 1996. Zarys klimatu Polski. Wydawnictwo Naukowe UAM, Poznań.

VAN DER MAAREL, E. 1979. Transformation of cover-abundance values in phytosociology and its effect on community similarity. Vegetatio. 39: 97-114. 